\title{
Light and electron microscopic study of the pathology and merogony of Goussia gadi (Apicomplexa: Coccidia) in the swimbladder wall of haddock Melanogrammus aeglefinus
}

\author{
C. M. Morrison ${ }^{1}$, J. P. Leger ${ }^{2}$, C. A. Morrison ${ }^{1}$ \\ ${ }^{1}$ Department of Fisheries and Oceans, Biological Sciences Branch, Halifax, Nova Scotia, Canada B3J 2S7 \\ ${ }^{2}$ Anatomy Dept, Dalhousie University, Halifax, Nova Scotia, Canada B4H 4H7
}

\begin{abstract}
Asexual and sexual stages in the life cycle of Goussia (Plagula) gadi (Fiebiger, 1913), parasites of haddock Melanogrammus aeglefinus, occur in loose connective tissue between the lobes of the gas gland and in the swimbladder wall. The asexual stages are usually found in the deeper layers, and the sexual stages towards the lumen of the swimbladder. There are many leukocytes in the lumens and walls of the blood vessels of the loose connective tissue, and phagocytes containing degenerating parasites and trophozoites are seen in the surrounding connective tissue. Various stages of the parasite and disintegrating host cells arc released into the lumen of the swimbladder, forming a yellowish exudate. Meruzultes form by sereral generations of endogenesis. The first generation, in which only 2 daughter meronts are formed (endodyogeny), may occur in the sporozoite after it has been released trom the sporocyst, when it is still within the oocyst membrane; in a free sporozoite, in a trophozoite which may be free or in a phagocyte. This may be repeated, so that a group of elongate, intertwined merozoites is formed. A second generation of rosettes of radiating meronts is formed by endopolygeny, usually in vacuoles of host cells which are reduced to a thin rim of vacuolated cytoplasm.
\end{abstract}

KEY WORDS: Coccidia Goussia gadi Haddock - Melanogrammus aeglefinus - Merogony - Swimbladder

\section{INTRODUCTION}

Goussia (Plagula) gadi (Fiebiger, 1913) is a coccidian parasite in gadoid fish from the North Atlantic and the Baltic Sea. It was first described in pollock Pollachius virens (Linnaeus, 1758) by M. Auerbach and in cod Gadus morhua Linnaeus, 1758 by J. Mueller (Fiebiger 1913), who described yellow matter consisting mainly of spores having a capsule consisting of 2 halves. $G$. gadi is also frequently found in the wall of the swimbladder of haddock Melanogrammus aeglefinus (Linnaeus, 1758) (Dykova \& Lom 1983, Upton et al. 1984). It has been recorded in haddock, cod and a single fourbeard rockling Enchelyopus cimbrius (Linnaeus, 1766) in Canadian waters (Odense \& Logan 1976. Morrison et al. 1986). Its prevalence varies seasonally and geographically, but has reached $84.1 \%$ in haddock on Browns Bank (NW Atlantic) (Scott 1981).
In the swimbladder Goussia gadi encounters high oxygen concentrations and a well-vascularised substrate high in nutrients, which probably enables it to multiply rapidly (Fiebiger 1913). The swimbladder of gadoids is physoclistous, and the spores accumulate as the disease progresses, filling most of the swimbladder with yellow matter. Mueller described such infected fish as emaciated, although Fiebiger found that this was not always the case (Fiebiger 1913). It has been suggested that the infection would interfere with the regulation of buoyancy, so that feeding and reproduction would be difficult (Odense \& Logan 1976). Only the anterior end of lightly infected swimbladders was filled with yellow matter, and a layer extended posteriorly along the ventral wall, becoming progressively thinner (Fiebiger 1913). Besides spores, droplets of lipid material, cholesterol platelets and fatty acid 'margarine needles' were found. 
Other coccidians found in swimbladders are Goussia caseosa, in the grenadier Macrourus berglax Lacépède (Lom \& Dykova 1982), and Goussia cichlidarum, found in various cichlid fish, especially Sarotherodon galilaeus (Landsberg \& Paperna 1985). The only developmental stages of $G$. caseosa found were sporulating oocysts. These were observed mainly in the gas gland of the swimbladder, but also in the mesenteric blood vessels, gall bladder and intestinal contents. The oocysts, sporocysts and sporozoites are larger than those of $G$. gadi, no open sporocysts were found within the swimbladder, and no developmental stages were found in the swimbladder wall. G. cichlidarum differs from $G$. gadi and $G$. caseosa in size, and also in that it develops within host cells which are displaced to the surface of the epithelial lining of the swimbladder (Paperna et al. 1986).

The light microscopic appearance of all stages of Goussia gadi has been described in detail and drawn (Fiebiger 1913), but the only stage studied using electron microscopy was the thick-walled sporocyst (Odense \& Logan 1976). By experimentally infecting cultured fish, Steinhagen (1991) found that the asexual stages of Goussia carpelli were only present for a short time, and thus would be difficult to find in wild, marine fish. However, the complete life cycle of G. gadi takes place in the wall of the swimbladder. The asexual stages are in the loose connective tissue of the wall, and according to Shulman \& Shtein (1962) their development is not intracellular, but takes place in interstitial spaces. Maturation of the spores occurs towards the internal surface of the swimbladder, and sporozoites are released to infect new parts of the wall (Fiebiger 1913, Shulman \& Shtein 1962). This situation provides a good opportunity to study all the developmental stages, although without the advantage of a timed series as could be obtained with experimentally infected fish. Here we present light micrographs of the developmental stages of G. gadi, previously shown only as drawings (Fiebiger 1913), and electron micrographs of these same stages. A variety of terms have been used in the literature for different asexual stages, but we refer to any process that results in the formation of merozoites as merogony, as suggested by Chobotar \& Scholtyseck (1982)

\section{MATERIALS AND METHODS}

Haddock were examined for infection by opening the body cavity and slitting open the ventral surface of the swimbladder. Goussia gadi infections were diagnosed by the presence of a yellowish waxy exudate in the swimbladder Eight infected swimbladders were sampled on cruises in July 1990 on Emerald, La Have,
Georges and Baccaro Banks, (NW Atlantic) and seven in. September 1990 on Emerald Bank. Nine fish were female, six were male; they varied in length from 44 to $61 \mathrm{~cm}$. Infected swimbladders from the July cruise were fixed whole in $1 \%$ glutaraldehyde and $4 \%$ formaldehyde in phosphate buffer (1G4F; McDowell 1978)

On return to the laboratory a longitudinal strip was removed from the anterior to the posterior part of the ventral swimbladder wall, and cut transversely into several pieces which were processed for paraffin and JB4 resin embedding for light microscopy. Paraffin sections were stained with Harris haematoxylin and eosin (Humason 1979), whereas JB4 resin sections were stained with methylene blue/basic fuchsin (Dougherty 1981), or a 1:50 dilution of $1 \%$ toluidine blue in $1 \%$ sodium borate.

Samples were also taken for transmission electron microscopy (TEM). The outer tough fibrous layer was removed, then the remaining tissues were cut into cubes not larger than $1 \mathrm{~mm}$, post-fixed in $1.5 \%$ osmium tetroxide, dehydrated in acetone and embedded in TAAB resin. Both JB4 and TAAB resins were obtained from Marivac, Inc., Halifax, NS, Canada. Sections 10.5 $\mu \mathrm{m}$ ) were stained in toluidine blue, and ultrathin gold and silver sections were stained in $25 \%$ uranyl acetate in methanol (Stempack \& Ward 1964) and lead citrate (Reynolds 1963).

Fixation of whole swimbladders was not always adequate for TEM, so small samples of swimbladder were removed from infected haddock at sea during the September cruise, and immediately cut into small cubes in 1G4F fixative. These were then processed for TEM in the same manner as the July samples.

\section{RESULTS}

Haddock swimbladders contained variable amounts of yellow material. Only one specimen, from Georges Bank, with small amounts of exudate with a wax-like consistency, proved to be uninfected. Coccidia were found in all other specimens, which contained significant accumulations of exudate, mainly around the gas gland. In histological sections there are few coccidia in the epithelium or rete mirabile of the gas gland, but disintegrating host tissue and asexual and sexual stages of the parasite are found in the loose connective tissue between the lobes of the gland, and in the swimbladder lumen (Figs. 1 \& 2). Many parasites are present in the loose connective tissue below the tunica interna of the swimbladder posterior to the gas gland, but not in the outer dense, fibrous layer (Fig. 3). Most meronts and gamonts are found deep in the loose connective tissue, towards the outer fibrous wall of the swimbladder, in large vacuoles giving a 'honeycomb' 
appearance to the tissue. Most sporocysts and degenerating host cells are found towards the lumen of the swimbladder There is mixing of the stages, since the sporocysts release sporozoites which reinfect the swimbladder.

Blood vessel walls in the loose connective tissue have a foamy appearance, cuused by many leukocytes in the endothelium and between the fibroblasts surrounding each blood vessel, and edema between the fibroblasts (Figs. 3, $4 \& 5$ ). There are phagocytes in the connective tissue around the blood vessels, some of which contain disintegrating parasites (Fig. 4). Amoeboid leukocytes containing electron-dense granules of varying sizes are seen in the endothelium and the connective tissue surrounding the blood vessels (Figs. 5 \& 6). There are also groups of granulocytes containing many large granules up to about $580 \mathrm{~nm}$ in diameter, which might surround a parasite (Fig. 7), although ingested parasites were not seen. The loose connective tissue layer of the swimbladder wall of haddock, like that of cod (Morrison 1987), contains a loose network of fibrils derived from fibroblasts (Morrison 1993), but few cells.

Sporozoite-shaped trophozoites with only remnants of or no apical complex occur in phagocytes (Fig. 8). The latter are probably macrophages, because they contain. many lysosomes as well as large lipid droplets. Many phagocytes have highly vacuolated cytoplasm containing myelin figures. The trophozoites are surrounded by a membrane, and in some specimens there is a thin layer of electron-dense material containing small vesicles between the membrane and the trophozoite. In some the layer is electron-transparent, and may form a large parasitophorous vacuole. The trophozoites contain a nucleus and a group of mitochondria, as well as lipid droplets and often a crystalloid body Beneath the pellicle are small electron-dense vesicles, especially at each end of the parasite, which may be in contact with the pellicle (Fig. 9). Similar trophozoites are found free between the host cells. In some trophozoites there is a double-membraned pellicle around a lobe extending from the nucleus (Fig. 10). This is an early stage in the formation of a first generation merozoite. In other trophozoites the merozoite is more elongate, and organelles are present within the pellicle (Fig. 11). Two first generation merozoites are present in some trophozoites (Figs. 12 \& 13). These contain all the nuclear material from the trophozoite, whose cyto- plasm apparently disappears by the end of this division, known as endodyogeny. Endodyogeny can occur in trophozoites which are still within the oocyst membrane (Fig 12), although usually this process occurs in free trophozoites, or in trophozoites within host cells Elongate merozoites curving around each other are found (Fig. 13). Two merozoites may be seen next to each other in the host cytoplasm, but division can take place more than once (Fig. 14). Groups of elongate convoluted merozoites attached to a residual body are seen, some within host cells, others free (Fig. 15). The merozoites contain peripheral osmiophilic vesicles and crystalloids. They are surrounded by the trilayered pellicle typical of coccidia (Chobotar \& Scholtyseck 1982), but the residual body is surrounded only by a unit membrane (Fig. 16).

Rounded uninucleate merozoites are found in vacuoles in the host cell cytoplasm, which is highly vacuolated, and often reduced to a thin layer (Fig. 17). These become either multinucleate meronts or microgamonts, or macrogamonts (Fig. 18) Early multinucleate meronts and microgamonts cannot be distinguished from each other (Fig. 19). Their cytoplasm contains mitochondria, endoplasmic reticulum and peripheral amylopectin granules (Fig 20). Some multinucleate meronts have the early stage of the second generation merozoite, a pellicle encircling a lobe of each nucleus (Fig. 21). Subpellicular microtubules are present, and there are cisternae of endoplasmic reticulum and vesicles above the nucleus (Fig. 22). There may be a micropore (Fig. 23), and a centriole in the apical cytoplasm (Figs. 23 \& 24).

Some meronts contain elongate second generation merozoites (Fig. 25); others are filled with radiating merozoites continuous with the residual body of the meront, which contains lipid droplets (Fig. 26) Rosettes of merozoites attached to the residual body of the mother meront are found, in which no cytoplasm remains between the merozoites (Figs. $27 \& 28$ ). The average size of 36 mature merozoites was $3.0 \mu \mathrm{m}$ wide (range 1.9 to $5.0 \mu \mathrm{m}$ ) and $16.1 \mu \mathrm{m}$ long (range 11.3 to $21.3 \mu \mathrm{m}$ ). The elongate nucleus is 2 to $3 \mu \mathrm{m}$ in diameter, and contains a prominent nucleolus. A small apical complex is present. This consists of a conoid and a few organelles which appear to be secretory. The latter are club-shaped and electron-dense, and open via a duct at the pellicle (Figs. $29 \& 30$ ). There are also peripheral amylopectin granules and mitochondria, and a Golgi

Abbreviations used in figures. $\mathrm{AG}=$ amylopectin granule; $\mathrm{BV}=$ blood vessel; $\mathrm{C}=$ conoid; $\mathrm{Ce}=\mathrm{centriole} ; \mathrm{Co}=\mathrm{collagen} ; \mathrm{Cr}=\mathrm{crys}-$ talloid body; $\mathrm{CT}=$ connective tissue; $\mathrm{E}=$ epithelium; $\mathrm{En}=$ endothelial cell; $\mathrm{Er}=$ erythrocyte $\mathrm{EL}=$ electron-dense layer; $\mathrm{ER}=$ endoplasmic reticulum; $F=$ fibroblast $F L=$ fibrous layer; $G=$ granule; $G B=$ Golgi body; $H C$ = host cell cytoplasm; $L=$ leukocyte; $\mathrm{Ly}=$ lysosome; $\mathrm{LD}=$ lipid droplet; $\mathrm{Ma}=$ macrogamont; $\mathrm{Me}=$ merozoites; $\mathrm{Mem}=$ membrane $;$ Mer $=$ meront $\mathrm{Mi}=$ mitochondrion; $\mathrm{Mic}=$ microtubule $\mathrm{Mp}=$ micropore $\mathrm{N}=$ neutrophil $\mathrm{Nu}=$ nucleus $; \mathrm{OM}=$ oocyst membrane $; \mathrm{OV}=$ osmiophilic vesicle; $\mathrm{P}=$ para site $; \mathrm{Pe}=$ pellicle $; \mathrm{Ph}=$ phagocyte $\mathrm{PV}=$ parasitophorous vacuole $; \mathrm{RB}=$ residual body $\mathrm{RM}=$ rete mirabile; $\mathrm{S}=$ sporocyst; $\mathrm{SM}=$ sporoblast or sporocyst membrane; $\mathrm{SO}=$ secretory organelle; $\mathrm{SW}=$ sporocyst $w_{a} l_{i} \mathrm{~V}=$ vesicle 


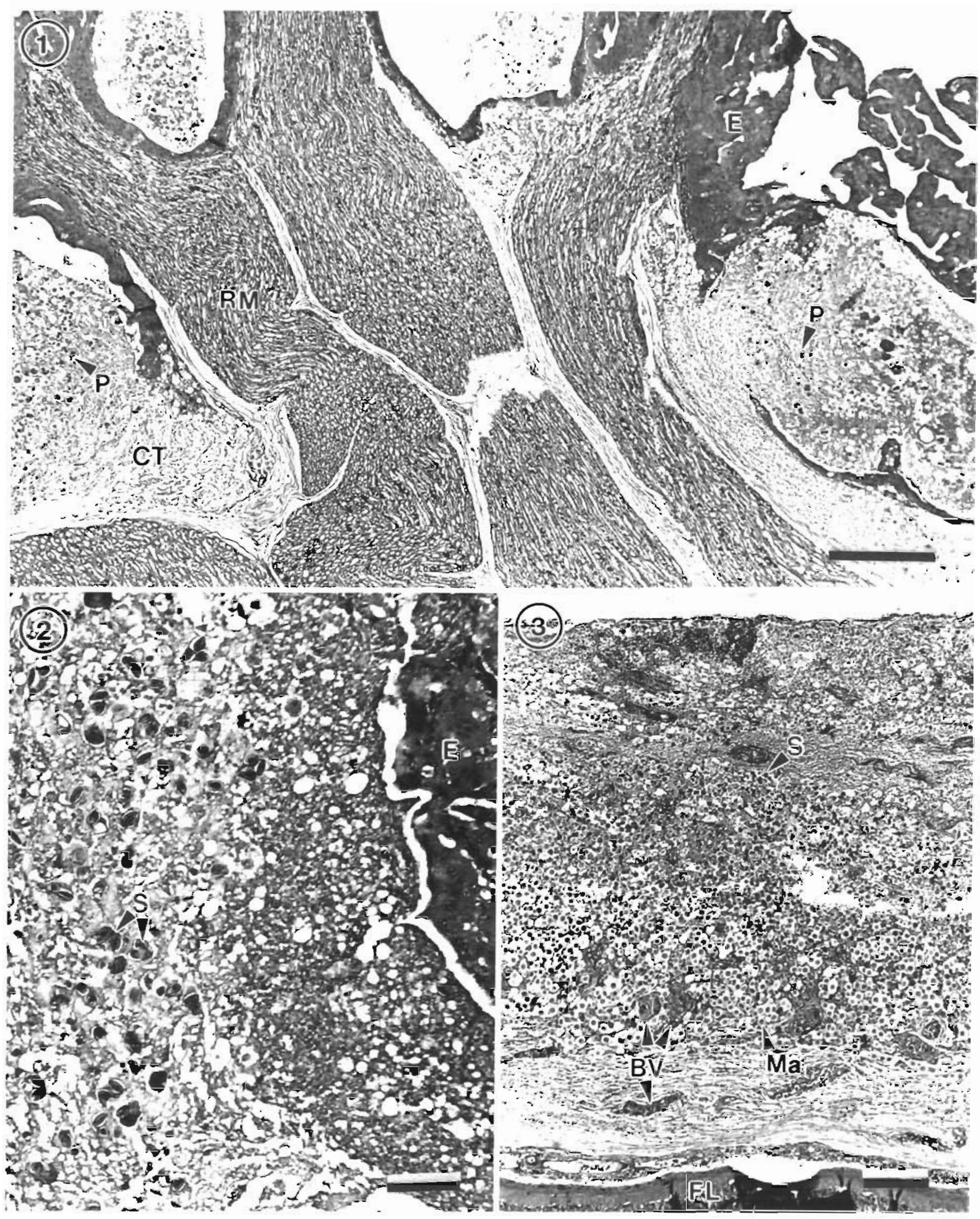

Figs. 1 to 3. Goussia gadi parasitizing Melanogrammus aeglefinus. Fig. 1. Various stages of the parasite and disintegrating host cells in the loose connective tissue between the lobes of the gas gland of the haddock. These extend through the epithelium of the gland into the lumen of the swimbladder. Paraffin; $H \&$ E; scale bar $=100 \mu \mathrm{m}$. Fig. 2. Sporocysts in the connective tissue below the epithelium of the swimbladder wall. Paraffin; H\& $E_{;}$scale bar $=250 \mu \mathrm{m}$. Fig. 3. Macrogamonts in parasitophorous vacuoles in the deeper layers of the haddock swimbladder wall, and sporocysts near the lumen. Paraffin; $\mathrm{H} \& E_{i} 5 c a l e ~ b a r=250 \mu \mathrm{m}$ 


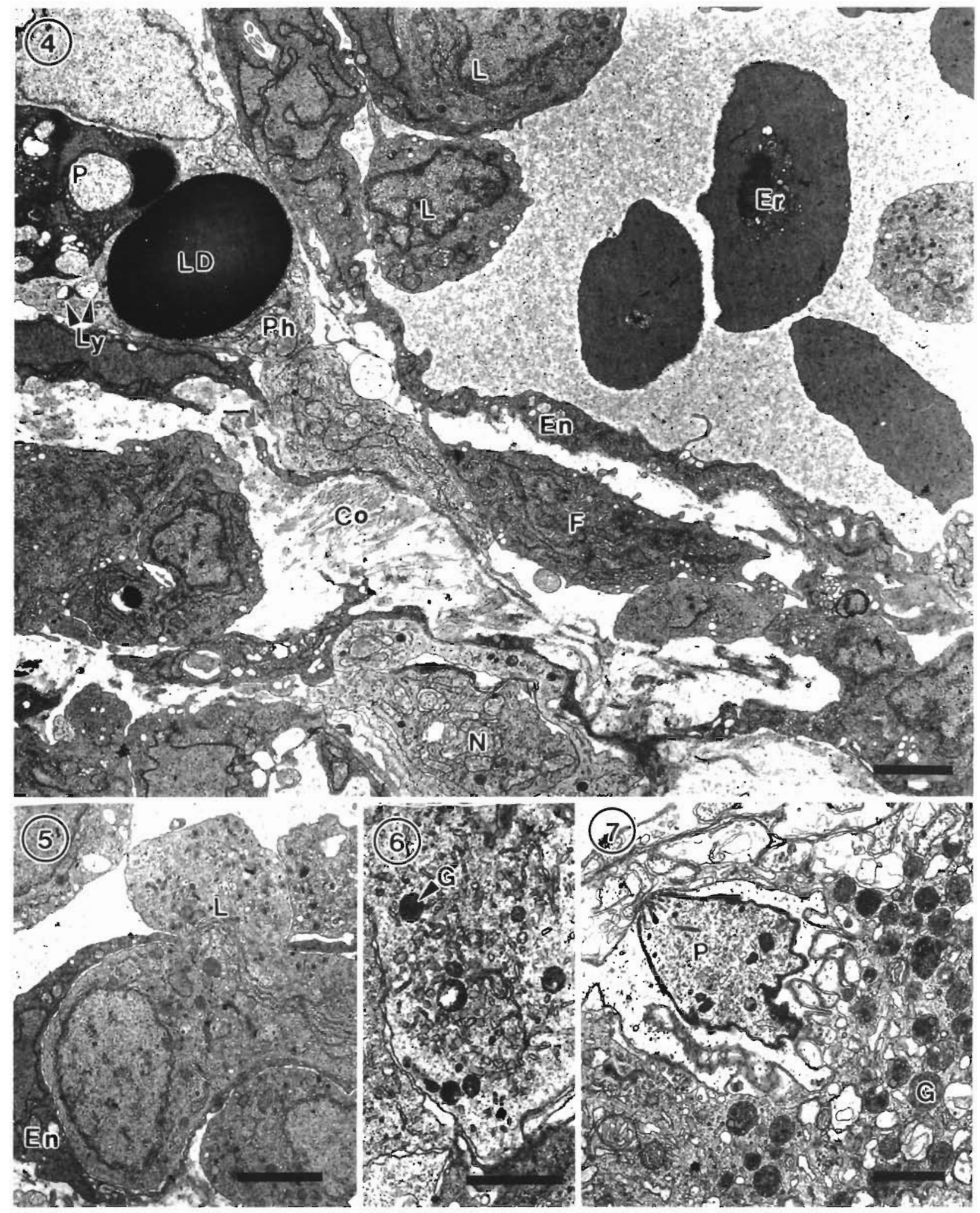

Figs. 4 to 7. Goussia gadi parasitizing Melanogrammus aeglefinus. Fig. 4. Leukocytes and erythrocytes in a blood vessel, and leukocytes between the fibroblasts external to the endothelıum. One phagocyte contains a large lipıd droplet and a disıntegrating parasite. Fibroblasts are separated by spaces, some of which contain collagen. TEM; scale bar $=2 \mu \mathrm{m}$ Fig. 5 . Amoeboid leukocyte (neutrophil?) in the endothelium. TEM; scale bar $=2 \mu \mathrm{m}$ Fig 6 . Leukocyte (neutrophil?) containing granules of varying sizes. TEM scale bar $=1 \mu \mathrm{m}$. Fig. 7. Leukocyte (eosinophil?) containing large granules, surrounding a sporozorte. TEM, 


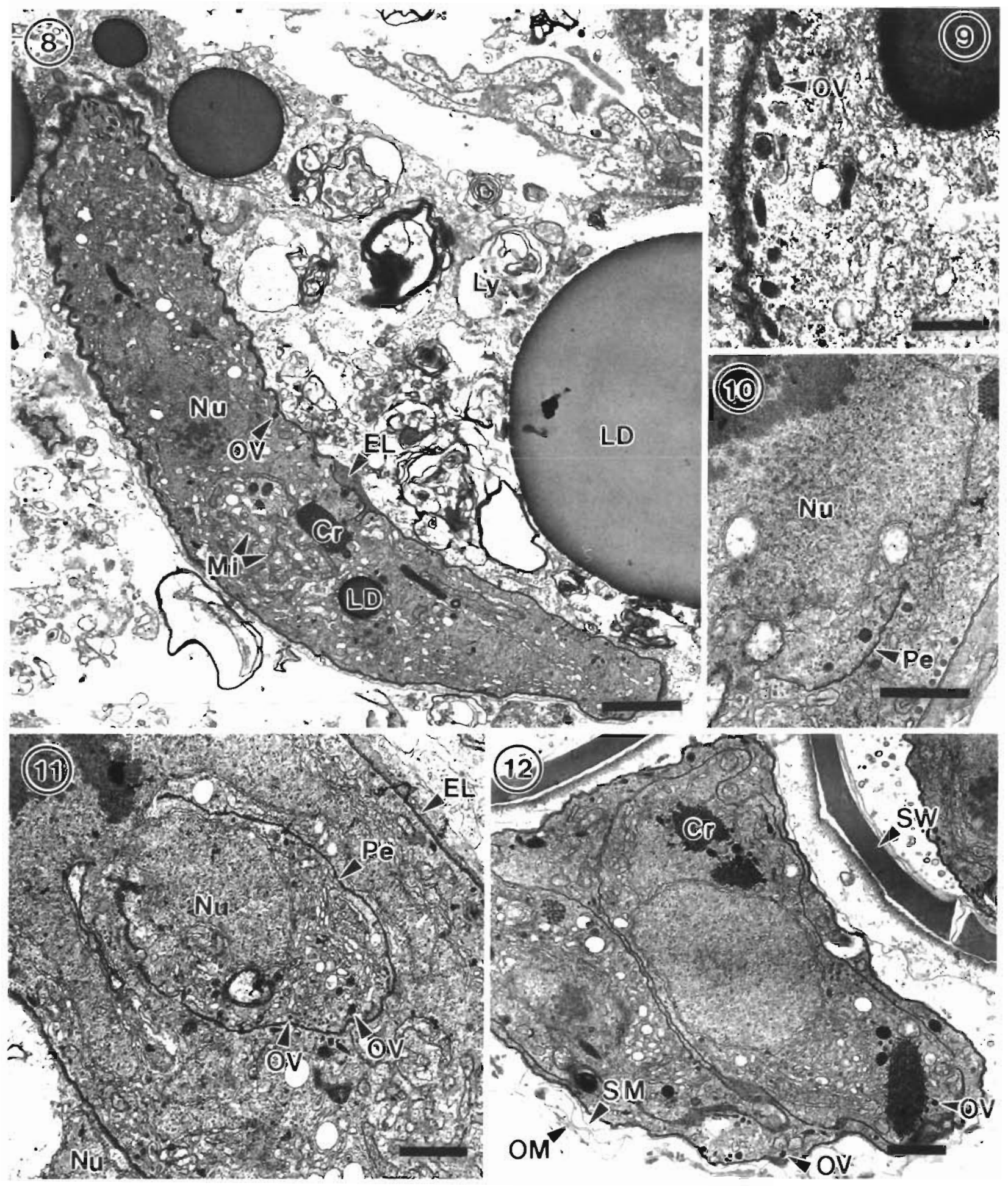

Figs 8 to 12 Goussta gadi parasitizing Melanogrammus aeclefinus. Fig. 8 . Trophozolte containing a crystalloid, lipid droplet group of mitochondria and osmiophilic vesicles beneath the pellicle. There are several lipid droplets and lysosomes in the disin tegrating host cell. TEM, scale bar $=2 \mu \mathrm{m}$. Fig. 9. Osmiophilic vesicles are contiguous with the trophozoite pellicle. TEM; Scale bar $=0.5 \mu \mathrm{m}$. Fig. 10. Merozolte pellicle forming around a lobe of the trophozolte nucleus. TEM; scale bar $=1 \mu \mathrm{m}$. Fig. 11 . The merozoite pellicle encircles a lobe of the trophozoite nucleus. Endoplasmic reticulum and osmiophilic vesicles are evident in the apical cytoplasm of the merozoite. TEM; scale bar $=1 \mu \mathrm{m}$. Fig. 12. Two merozoites in a trophozoite. The latter, along with sporocysts containing sporozoltes which have not been released, is surrounded by the oocyst membrane and remains of the sporocyst membrane. TEM, scale bar $=1 \mu \mathrm{m}$ 


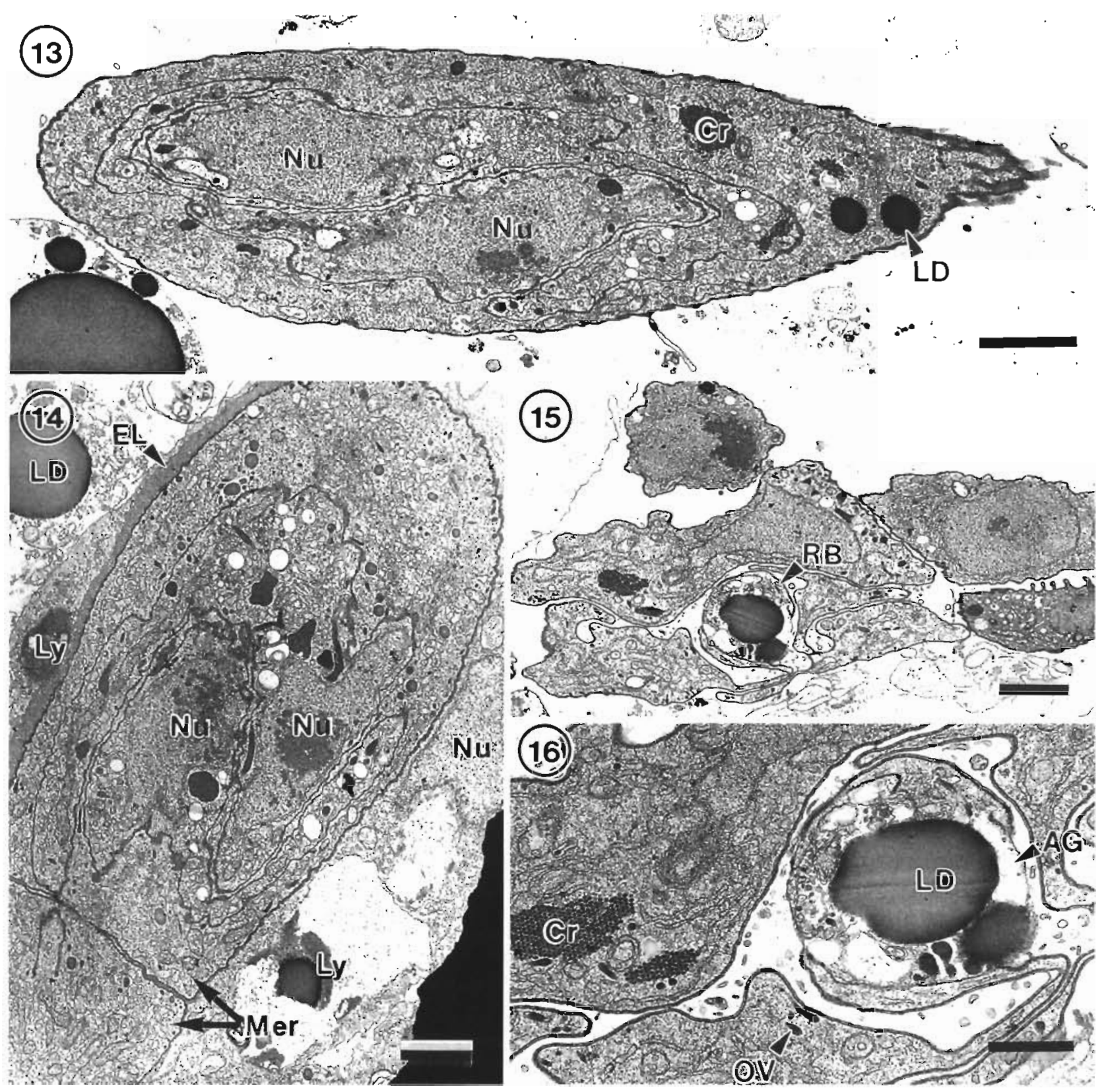

Figs. 13 to 16. Goussia gadi parasitizing Melanogrammus aeglefinus. Fig. 13. Two convoluted merozoites in a free trophozoite TEM; scale bar $=2 \mu \mathrm{m}$. Fig. 14. Two adjoining meronts each contain 2 merozoites. An electron-dense layer separates the meronts from the host cell cytoplasm containing lysosomes. TEM; scale bar $=1 \mu \mathrm{m}$. Fig. 15 . Group of merozoites with central residual body. TEMi scale bar $=2 \mu \mathrm{m}$. Fig. 16. Same group of merozoites at a higher magnification. Lipid droplets and amylopectin granules are present in the residual body, and merozoites containing crystalloid bodies and osmiophilic vesicles are surrounded by a pellicle. TEM; scale bar $=1 \mu \mathrm{m}$

apparatus anterior to the nucleus (Fig. 29). In some merozoites the conoid is protruded (Fig. 30), and small crystalloid formations occur in the cytoplasm (Fig. 31). Merozoites are surrounded by a pellicle, which is not present around the residual body (Fig. 32). Some large meronts appear to be dividing in two (Fig. 33), and there are vacuoles containing 2 rosettes of merozoites (Fig. 34)

\section{DISCUSSION}

Landsberg \& Paperna (1985) state that Goussia gadi develops in the gas gland but, as shown in this study, the gland itself is not affected, and the parasites develop only in loose connective tissue surrounding the rete mirabile of the gland. The finding by Fiebiger (1913) that there were no coccidia in the epithelial cells 


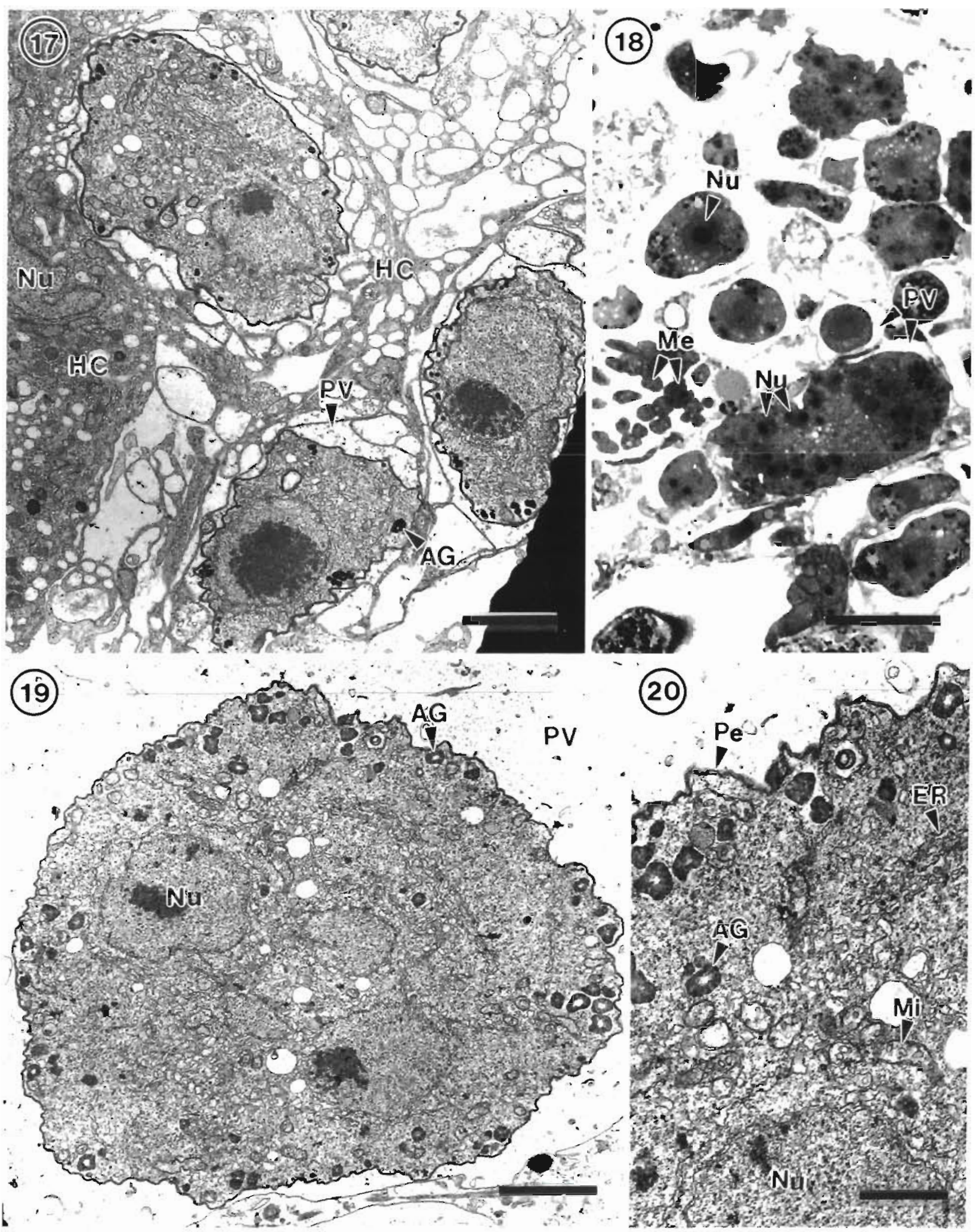

Figs, 17 to 20. Goussia gadi parasıtızıng Melanogrammus aeglefinus. Fig. 17. Rounded merozoites in developing parasitophorous vacuoles. Vacuolated host cell cytoplasm surrounds the parasites. TEM; scale bar $=2 \mu \mathrm{m}$ Fig. 18. Uninucleate and multınucleate meronts and gamonts in parasitophorous vacuoles $05 \mu \mathrm{m}$ section of EM sample staned with toluidine blue; $\$ \mathrm{cale}$ bar $=50 \mu \mathrm{m}$. Fig. 19. Rounded multinucleate meront or microgamont in vacuole. The host cell is reduced to a membrane. TEM; scale $\overline{b a r}=2 \mu \mathrm{m}$. Fig. 20. Pellicle of same multunucleate meront or microgamont at a higher magnification, showing trilayered pellicle, numerous amylopectin granules, mitochondna and vesicles of endoplasmic reticulum. TEM; scale bar $=1 \mu \mathrm{m}$ 

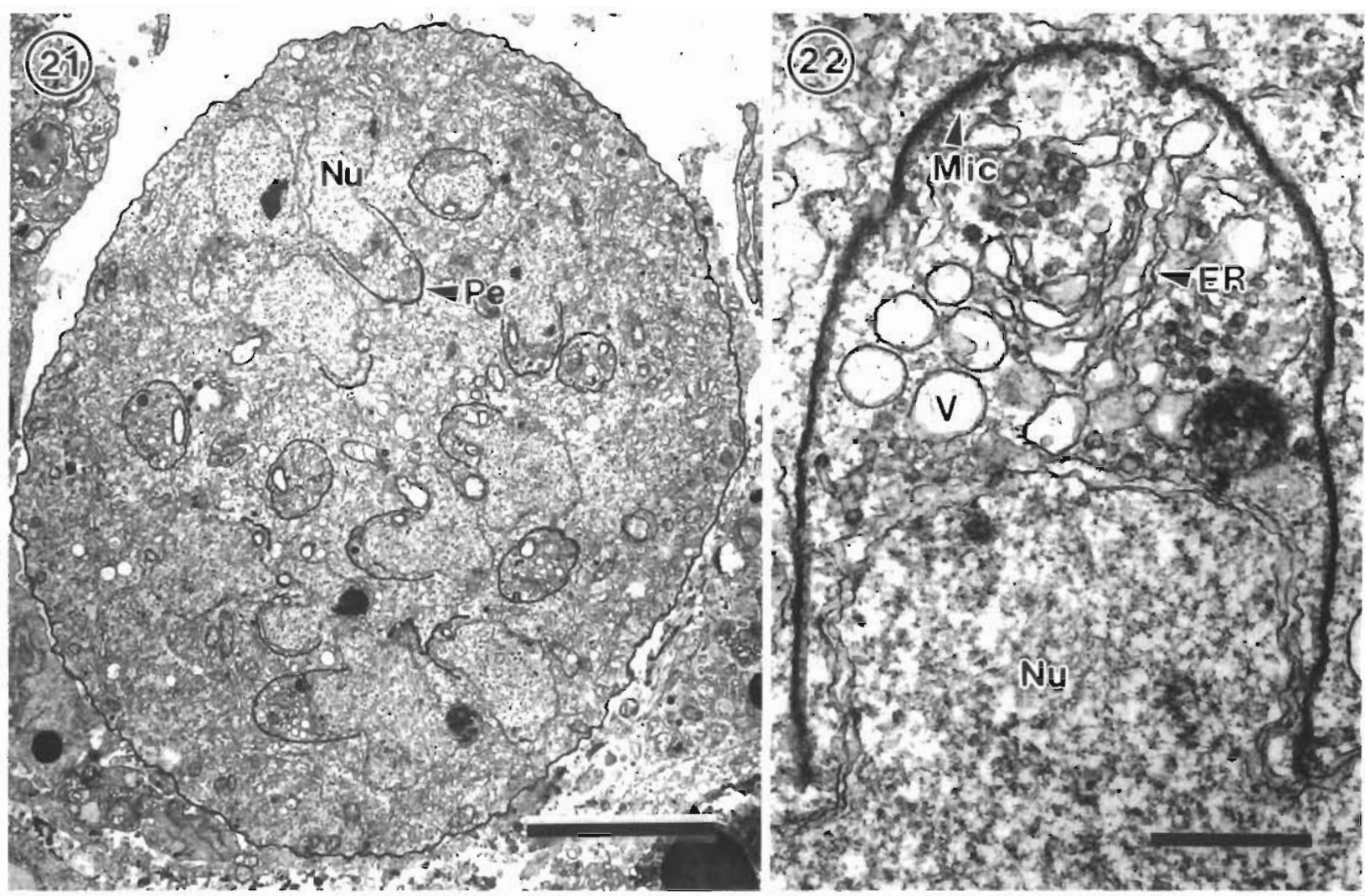

(23) 3 Mp

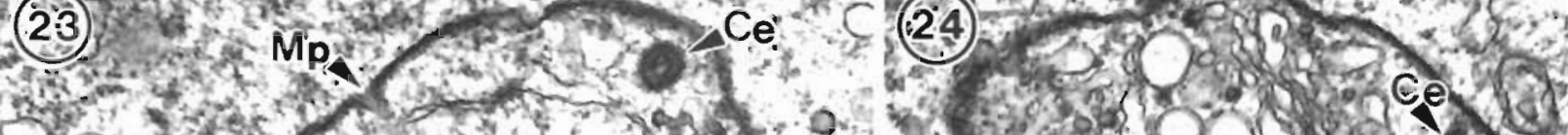

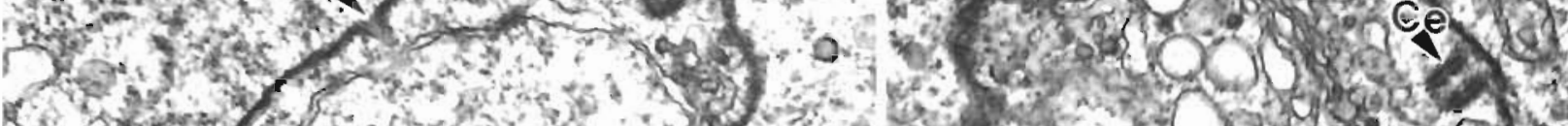

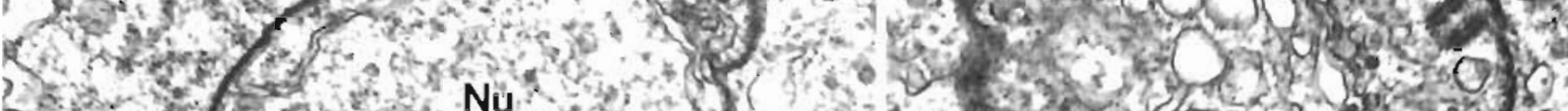
2.

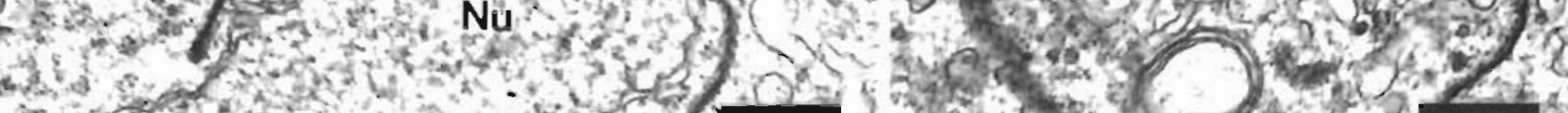

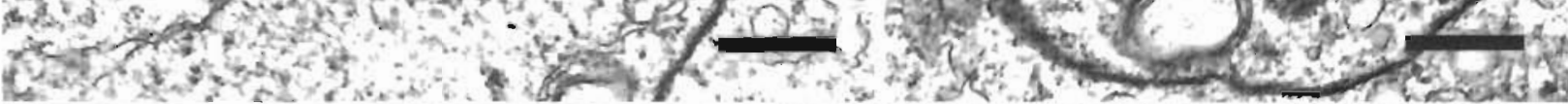

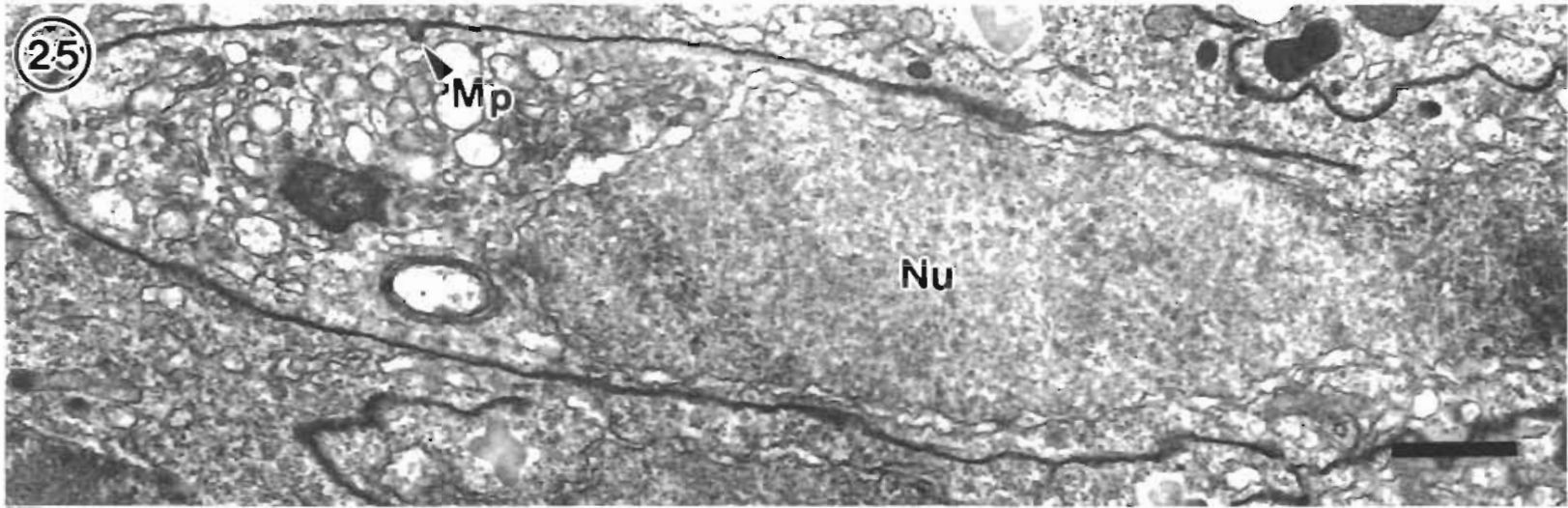

Figs 21 to 25. Goussia gadi parasitizing Melanogrammus aeglefinus. Fig. 21. Multınucleate meront Pellıcles of the second gen eration of merozoites enclose lobes of the nuclei. TEM, scale bar $=5 \mu \mathrm{m}$. Fig. 22 . Developing second generation merozolte. There are round vesicles and cisternae of endoplasmic reticulum between the nucleus and the pellicle, and microtubules beneath the pellicle. TEM; scale bar $=0.5 \mu \mathrm{m}$. Fig. 23 Developing second generation merozoite with a micropore, and a centriole in traverse section. TEM; scale bar $=0.5 \mu \mathrm{m}$. Fig. 24 . Developing second generation merozoite with a centriole in longitudinal section TEM, scale bar $=0.5 \mu \mathrm{m}$. Fig. 25. Elongate second generation merozoite with a micropore, and vesicles in the apıcal cytoplasm TEM. 


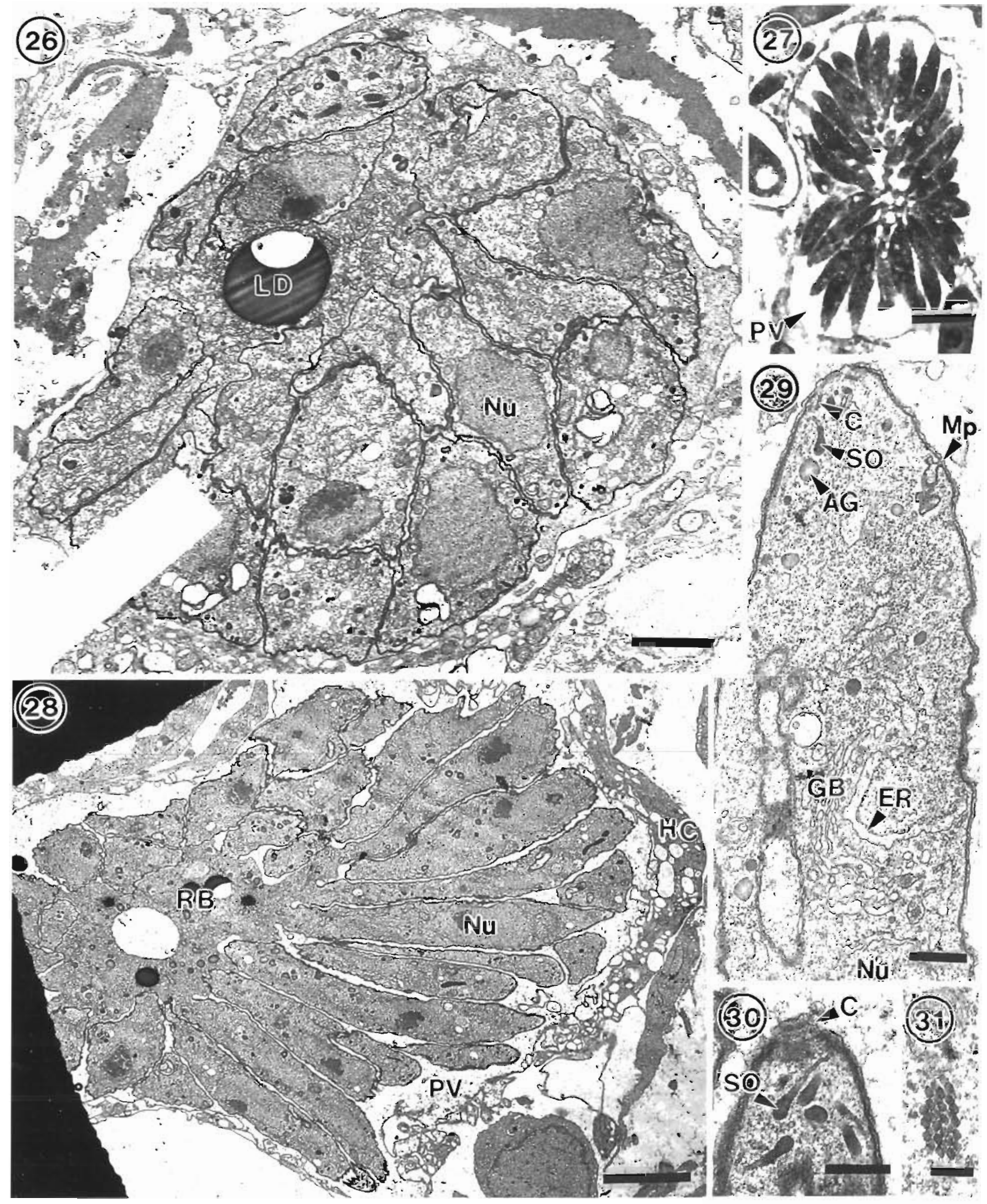

Figs 26 to 31 Goussia gadi parasiting Melanogrammus aeglefinus. Fig. 26. Developing second generation merozoites are attached to the residual bodv of the meront, and are surrounded by the cytoplasm of this meront. TEM; scale bar $=2 \mu \mathrm{m}$. Fig. 27 Second generation merozoltes form a rachating pattern in a parasitophorous vacuole. The host cell is reduced to a thin layer. JB4 resin; methylene blue/basic fuchsin stain; scale bar $=10 \mu \mathrm{m}$. Fig. 28 . Second generation merozoites contain elongate nuclei with a single nucleolus. and lipid droplets are evident in the residual body. TEM; scale bar $=5 \mu \mathrm{m}$. Fig. 29. Apical portion of second generation merozoite. A small conoid, secretory organelle, micropore with associated feeding vacuole, Golgi apparatus, endoplasmic reticulum, amylopectin granules and vesicles are evident. TEM; scale bar $=0.5 \mu \mathrm{m}$. Fig. 30 . Conoid apparatus extruded from apex of second generation merozoite. TEM; scale bar $=0.5 \mu \mathrm{m}$. Fig. 31. Crystalloid body of second generiation merozoite 


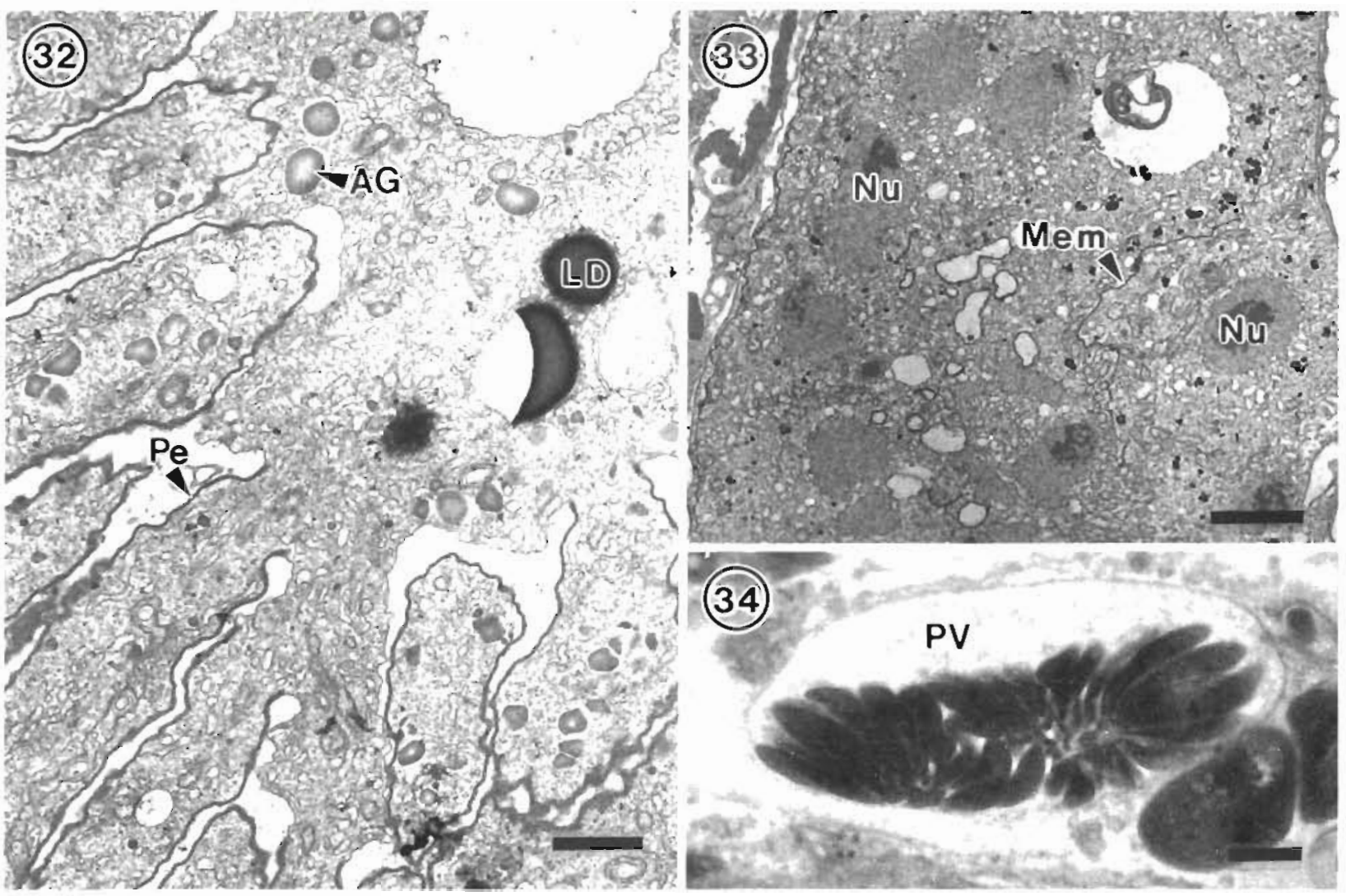

Figs 32 to 34 Goussia gadi parasitizing Melanoglammus aeglefinus. Fig. 32. The resıdual body of the meront containing lipıd droplets is surrounded by a single membrane, second generation merozoites are surrounded by a pellicle. TEM; scale bar $=1 \mu \mathrm{m}$ Fig 33. Multinucleate meront is partially divided into two by a membrane. TEM; scale bar $=25 \mu \mathrm{m}$. Fig 34 . Two rosettes of second generation merozoites in a host cell vacuole. JB4, toluidine blue; scale bar $=10 \mu \mathrm{m}$

of the swimbladder is corroborated by the present study. The sporozolte-shaped trophozoltes usually tound in phagocytes but also found free show no signs of degeneration, and appear to be able to enlarge and develop in the phagocyte. They may be denved from sporozoites or merozoltes. Presumably those undergoing endodyogeny are derived from sporozoltes, sunce similar stages were also found within the oocyst membrane Fiebiger (1913) described multinucleate sporozoites within the oocyst membrane, although he shows drawings only of binucleate stages, as found in this study The osmiophilic vesicles at the ends of the trophozolte may be the remnants of the apical complex, and seem to be the means by which the parasite gains nutrients and disposes of waste products by pınocytosis. According to Chobotar \& Scholtyseck (1982), coccidian sporozoltes have often been reported in macrophages, and can repeatedly invade and escape from them. However, developmental stages such as the endodyogeny found in $G$. gad are rarely found in other coccidians in phagocytes The electron-dense layer around some trophozoltes in phagocytes may be an early stage in the formation of the more obvious electron-lucent parasitophorous vacuole. The phagocytes apparently disintegrate and are reduced to membranous sacs, like the host cells containing the developing stages of $G$ caseosa and $G$. cichlidarum (Landsberg \& Paperna 1985, Paperna et al 1986).

It was difficult to identify the leukocytes described in the present study, because specific stans for blood cell types were not carred out, and the ultrastructure of the leukocytes of cod has not been studied. The literature on tish granulocytes is contradictory (Ellis 1977). In the present study the amoeboid granulocytes containing numerous granules of varying sizes are probably neutrophuls (heterophils), the most commonly reported granulocyte in the peripheral blood of fish, although the granules are not elongate and striated as described in some species (Hawkins et al. 1981). The leukocytes containing numerous large, dense granules are probably eosinophils, and the granules are the same size as those reported $ı$ n eosınophils by Hawkıns et al (1981) Little is known about the function of these cells, although neutrophils migrate to inflammatory sites (Ellis 1977) Since there is an extensive host reaction to Goussia gadi in the swimbladder, it is likely that 
the host may sometimes survive the infection. There is usually little host response to coccidian infections in fish, but extensive leukocyte infiltration was also found in response to infection by Calyptospora funduli (Hawkins et al. 1981). The monocytes contained residual bodies, but no lipid droplets as reported in G. gadi infections. In the latter, lipid probably accumulates due to the ingestion of stages of G. gadi containing lipid droplets.

Fiebiger (1913) and Shulman \& Shtein (1962) report that the stages of Goussia gadi usually develop free in the connective tissue, but in the present account they were often found to be intracellular. It is not known whether phagocytes, probably macrophages, are the normal site of infection by sporozoites of $G$. gadi, or whether this only occurs in more advanced infections, such as those we studied, where numerous phagocytes had invaded the loose connective tissue layer of the swimbladder wall via the bloodstream. The merozoites resulting from endodyogeny could infect phagocytes or another type of host cell, such as a fibroblast. However, the original host cell type is difficult to determine since the cytoplasm around developing gamonts and multinucleate meronts, if still present, is reduced to a thin layer and is highly vacuolated; often only a membrane remains. However, no cell junctions were found between the host cells, indicating that they were originally motile phagocytes. Moreover, no other host cell type is present in large numbers in the loose connective tissue of the swimbladder wall (Morrison 1987).

Nothing is known about the transmission of Goussia gadi to other hosts, although the possibilities are discussed by Fiebiger (1913). Like many species of Goussia, the life-cycle of $G$. gadi takes place in an extra-intestinal site where oocysts have no means of discharge from the living host (Overstreet et al. 1984). Fiebiger suggests that infected fish could be ingested by larger fish, but that the most likely mode of transmission is by death of the host, millions of spores being liberated after the abdominal and swimbladder. walls disintegrate. Sporozoites may be released from the spores after ingestion by the piscine host, penetrate the intestinal epithelium, enter the bloodstream and be carried to the swimbladder. Since sporozoites easily enter phagocytes, and trophozoites of $G$ gadi are found in phagocytes in the connective tissue of the swimbladder, they could be transported in the bloodstream in this manner Presumably sporozoites could also be transported from the swimbladder to the intestine, and be released with the faeces to infect other hosts. Sporocysts have been reported in blood vessels near the swimbladder (Odense \& Logan 1976), and so could presumably enter or exit the swimbladder by this route, although it is difficult to imagine how they could cross the endothelium lining the blood vessel.
An intermediate host is not essential for Goussia gadi, since it is able to complete its cycle within the swimbladder, but one could be involved in transmission to another host. In $G$. carpelli (Steinhagen \& Körting 1990) direct transmission by faecal contamindtion can occur, but reinfection of carp was only possible with a tubificid intermediate host. Overstreet (1981) has suggested that haddock are more likely to be infected by ingestion of a secondary host such as a crustacean containing $G$. gadi than by ingestion of an infected gadoid or its remains, since they are smallmouthed bottom feeders; but according to Scott \& Scott (1988) they also eat fish such as elvers, herring, argentines, sand lance, capelin and silver hake. G. gadi was not found in 34 silver hake examined by Odense \& Logan (1976).

In Goussia gadi there appear to be 2 generations of merozoites, dividing by 2 different types of endogenesis. The first type, endodyogeny, in which 2 daughter organisms form, using up the mother cell (Chobotar \& Scholtyseck 1982), has rarely been described in piscine coccidians (Landsberg \& Paperna 1987, Paperna 1991, Kim \& Paperna 1992, Lukes 1992). Since there can be more than one cycle of this type of division, a group of first generation merozoites could be formed as shown in Figs. 15 \& 16

First generation merozoites then apparently form multinucleate meronts which divide by endopolygeny, giving rise to a rosette which may contain more than 40 second generation merozoites (Fiebiger 1913). These differ from the groups of first generation merozoites in being more numerous and less convoluted, and in possessing numerous amylopectin granules and a small apical complex. The secretory organelles associated with this complex are open at the surface of the merozoite and are shaped like rhoptries, but they do not open through the conoid, and are not obviously paired. It has been suggested that micronemes may be an early stage in the formation of rhoptries, and may form. a structural unit with them (Chobotar \& Scholtyseck 1982), so the secretory organelles may be the forerunners of this system. The second generation merozoites were found to be longer in the present study than in the study by Fiebiger (1913), who reported that they were $8.0 \times 2.5 \mu \mathrm{m}$. Endopolygeny has been described in several piscine coccidia (Paterson \& Desser 1981 Steinhagen 1991), but Goussia gadi differs from these coccidia in that no vesicles are formed around the developing merozoites, and more than one rosette may be found in a common vacuole, as reported by Fiebiger (1913). The radiating form of merogony found in $G$. gadi would suggest development by exogenesis, but no early stages of exogenesis, in which the apical complexes of the merozoites develop next to the limiting membrane of the meront, were found (Paterson \& 
Desser 1981, Jastrzębski 1989). Although the merozoites originate internally in association with nuclei during endogenesis, in later development they assume a peripheral location and grow outward at the surface, so that the appearance is similar to that of exogenesis (Chobotar \& Scholtyseck 1982).

Acknowledgements. We thank Drs G. McCelland and D. Scarratt for their careful reviews of the manuscript, and helpful comments.

\section{LITERATURE CITED}

Chobotar, B., Scholtyseck, E. (1982). Ultrastructure. In: Long, P. L. (ed.) The biology of the coccidia. Edward Arnold, London, p. 101-166

Desser, S. S. (1981). The challenge of fish coccidia. J. Protozool. 28: 260-261

Dougherty, W. J. (1981). Preparation and staining of semi-thin sections of tissues embedded in water-soluble methacrylate for light microscopy. In: Clark, G. (ed.) Staining procedures, 4 th edn. Williams and Wilkins Co., Baltimore, p. $27-38$

Dykova, I., Lom, J. (1983). Fish coccidia: an annotated list of described species. Folia parasitol (Praha) 30: 193-208

Ellis, A. E. (1977). The leucocytes of fish: a review. J. Fish Biol. 11: $53-491$

Fiebiger, J. (1913). Studien über die Schwimmblasencoccidien der Gadusarten (Eimeria gadi n.sp.). A.rch. Protistenkd. 31: 95-137

Hawkins, W. E., Solangi, M. A., Overstreet, R. M. (1981). UItrastructural effects of the coccidium, Eimeria funduli Duszynski, Solangi and Overstreet, 1979 on the liver of killifishes. J. Fish Dis. 4: 281-285

Humason, G. L. (1979). Animal tissue techniques, 4th edn. W. H. Freeman, San Francisco

Jastrzębski, M. (1989). Ultrastructural study of the development of Goussia aculeati, a coccidium parasitizing the three-spined stickleback Gasterosteus aculeatus. Dis. aquat. Org. 6: $45-53$

Kim, S. H., Paperna, I. (1992). Fine structure of epicytoplasmic stages of Eimeria vanasi from the gut of cichlid fish. Dis. aquat. Org. 12: 191-197

Landsberg, J. H., Paperna, I. (1985). Goussia cichlidarum n.sp. (Barrouxiidae, Apicomplexa), a coccidian parasite in the swimbladder of cichlid fish. Z. Parasitenkd. 71: $199-212$

Landsberg, J. H., Paperna, I. (1987). Intestinal infections by Eimeria (S.L.) vanasi n.sp. (Eimeriidae, Apicomplexa, Protozoa) in cichlid fish. Annls Parasit. hum. comp. 62: 283-293

Lom, J., Dykova, I. (1982). Some marine fish coccidia of the genera Eimeria Schneider, Epieimeria Dykova and Lom and Goussia Labbé. J. Fish Dis. 5: 309-321

Lukes, J. (1992). Life cycle of Goussia pannonica (Molnar, 1989) (Apicomplexa, Eimeriorina), an extracytoplasmic coccidium from the White Bream Blicca bjoerkna. J. Protozool. 39: $484-494$
McDowell, E. M. (1978). Fixation and processing. In: Trump, B. F., Jones, R. T (eds.) Diagnostic electron microscopy. 1. John Wiley and Sons, New York

Morrison, C. M. (1987). Histology of the Atlantic cod, Gadus morhua: an atlas. Part 1. Digestive tract and associated organs. Can. Spec. Publ. Fish. Aquat. Sci. 98

Morrison, C. M. (1993). Histology of the Atlantic cod, Gadus morhua: an atlas. Part 4. Eleutheroembryo and larva. Can. Spec. Publ. Fish. Aquat. Sci. 119

Morrison, C. M., McClelland, G., Cornick, J., Marcogliese, D. (1986). Parasites and diseases of some marine finfish off Nova Scotia. Can. Tech. Rep. Fish. Aquat. Sci. 1424

Odense, P. H. Logan, V. H. (1976). Prevalence and morphology of Eimeria gadi (Fiebiger, 1913) in the haddock. J. Protozool. 23: 564-571

Overstreet, R. M. (1981). Species of Eimeria in nonepithelial sites. J. Protozool. 28: 258-260

Overstreet, R. M., Hawkins, W. E., Fournie, J W. (1984). The coccidian genus Calyptospora n. g. and family Calyptosporidae n. fam. (Apicomplexa), with members infecting primarily fishes. J. Protozool. 3: 332-339

Paperna, I. (1991). Fine structure of Eimeria (s. 1.) vanasi merogony stages in the intestinal mucosa of cichlid fishes Dis. aquat. Org. 10: 195-201

Paperna, I., Landsberg, J. H., Feinstein, N. (1986). Ultrastructure of the macrogamont of Coussia cichlidarum Landsberg and Paperna, 1985, a coccidian parasite in the swimbladder of cichlid fish. Annls Parasit. hum. comp. 61: $511-520$

Paterson, W. B., Desser, S. S. (1981). An ultrastructural study of Eimeria iroquoina Molnar and Fernando, 1974 in experimentally infected fathead minnows (Pimephales promelas, Cyprinidae). 3. Merogony. J. Protozool. 28: 302-308

Reynolds, E. S. (1963). The use of lead citrate at a high $\mathrm{pH}$ as an electron-opaque stain in electron microscopy. J Cell Biol. 17: 208-212

Scott, J. S. (1981). Alimentary tract parasites of haddock (Melanogrammus aeglefinus L.) on the Scotian Shelf. Can. J. Zool. 59: 2244-2252

Scott, W. B., Scott, M. G. (1988). Atlantic fishes of Canada Can. Bull. Fish. Aquat. Sci. 219

Shulman, S. S., Shtein, G. A. (1962). Phylum Protozoa. Unicellular animals. In: Bykhovskii, B. E. (ed.) Key to parasites of freshwater fish of the U.S.S.R. Acad. Sci. S.S.S.R., Moscow, Leningrad. (Transl. and republ. by Isrdel Prog. Sci. Transl., Jerusalem, p. 5-235)

Steinhagen, D. (1991). Ultrastructural observations on merogonic and gamogonic stages of Goussia carpelli (Apicomplexa, Coccidia) in experimentally infected common carp Cyprinus carpio. Eur. J. Protistol. 27:71-78

Steinhagen, D., Körting, W. (1990). The role of tubificid oligochaetes in the transmission of Goussia carpelli. J. Parasitol. 76: 104-107

Stempack, J. G., Ward, R. T. (1964). An improved staining method for electron microscopy. J. Cell Biol. 22: 697-701

Upton, S. J., Reduker, D. W., Current, W. L., Duszynski. D. W. (1984). Taxonomy of North American fish Eimeriidae. NOAA Tech. Rep. NMFS 11, Washington, DC

Manuscript first received: March 1, 1993

Revised version accepted: July 5, 1993
Responsible Subject Editor: W. Körting, Hannover, Germany 